Article

\title{
"I Like It like That": A Study on the Relationship between Psychological Capital, Work Engagement and Extra-Role Behavior
}

\author{
Maria Luisa Giancaspro ${ }^{1}$ (D) , Antonino Callea ${ }^{2}$ (D) and Amelia Manuti ${ }^{1, *(D)}$ \\ 1 Department of Education, Psychology, Communication, University of Bari, 70121 Bari, Italy; \\ maria.giancaspro@uniba.it \\ 2 Department of Human Sciences, LUMSA University, 00193 Rome, Italy; a.callea@lumsa.it \\ * Correspondence: amelia.manuti@uniba.it
}

check for updates

Citation: Giancaspro, M.L.; Callea, A.; Manuti, A. "I Like It like That": A Study on the Relationship between Psychological Capital, Work

Engagement and Extra-Role Behavior. Sustainability 2022, 14, 2022. https:// doi.org/10.3390/su14042022

Academic Editor: Hyo Sun Jung

Received: 29 November 2021

Accepted: 7 February 2022

Published: 10 February 2022

Publisher's Note: MDPI stays neutral with regard to jurisdictional claims in published maps and institutional affiliations.

Copyright: (C) 2022 by the authors. Licensee MDPI, Basel, Switzerland. This article is an open access article distributed under the terms and conditions of the Creative Commons Attribution (CC BY) license (https:// creativecommons.org/licenses/by/ $4.0 /)$.

\begin{abstract}
Starting from the Positive Organizational Behavior movement, several studies showed that some personal resources and some contextual features within the working context might encourage individuals and groups in thriving, thus providing a concrete competitive advantage for organizations. Among the individual factors, psychological capital (PsyCap) received a special interest because it was proved to promote positive work attitudes and behaviors. The present study aimed to investigate the positive effect of PsyCap on extra-role behaviors considering the mediating role of work engagement. A mediational hypothesis was tested via SEM on 1219 Italian employees, balanced for gender. Results suggested that work engagement partially mediated the positive relationship between PsyCap and extra-role behaviors. The present study shed a light on the psychological mechanisms according to which PsyCap positively affects extra-role behaviors. In line with the Positive Organizational Behavior Movement Theory, personal resources, i.e., PsyCap, tend to improve work engagement that, in turn, tends to promote positive behaviors at work. Finally, the present study discussed results especially in terms of practical implications in order to promote employees' PsyCap in organizational setting.
\end{abstract}

Keywords: positive organizational behavior; PsyCap; extra-role behavior

\section{Introduction}

Over the past decades, the issue of People Management has undoubtedly become a priority for research and practice in the field. Abundant evidence has confirmed the positive relationship between human resource management practices, employees' motivation and engagement, organizational performance, competitive advantage, customer satisfaction, and reputation [1,2]. Therefore, unanimously, scholars and practitioners engaged in different disciplinary domains, ranging from management science to organizational behavior, agreed with the evidence that employees, with their knowledge, their skills, their abilities, and personal features, are the most important intangible asset of the organization, the human capital that potentially could make a difference in many respects and could add value to the core business.

This assumption is largely echoed by the Positive Organizational Behavior (POB) movement, which is a quite recent stream of research within psychology studying the individual and contextual characteristics that allow people and organizations to flourish and increase their competitive advantage. The center of $\mathrm{POB}$ is the need to merge theory and research about human resource strengths and psychological resources that find application of such knowledge and skills in organizational contexts [3,4]. Accordingly, this positive approach places psychology at the service of management and business, thus concretely helping organizations in creating sustainable performance [5]. To enlarge the paradigm, a further employee-centered point of view is added to a management and performance-driven view, which suggests that the study of POBs must also focus on goals 
such as employee happiness and health [6], recommending the development of business strategies that have a positive impact on employee well-being, where a win-win situation for both the organization and its employees can be drawn [7]. In this vein, this approach focuses on successful performance in organizations and identifying the conditions that allow employees to thrive, feel good at work, and therefore work harder and better. Accordingly, empirical research in the field of Positive Organizational Behavior [8] could give a precious contribution to HR practice by studying "what is positive, flourishing, and life-giving in organizations. Positive refers to the elevating processes and outcomes in organizations. Organizational refers to the interpersonal and structural dynamics activated in and through organizations, specifically considering the context in which positive phenomena occur" [9] (p. 731).

In line with these theoretical speculations, empirical evidence has confirmed the reciprocal beneficial relationship between a people-based management, individual engagement, and positive organizational outcomes. Luthans and Youssef [4], for instance, have argued that the characteristics of the organizational context could increase the positive attitudes and abilities of its human resources, and consequently could result in positive behaviors (e.g., organizational citizenship behaviors (OCBs) and extra-role behavior). In a similar vein, Luthans et al. [10] showed that a positive management of employees' personal resources could have long-term benefits both for individuals and organizations. In this perspective, Psychological Capital (PsyCap), meant as the entirety of positive features managed by individuals at work (e.g., self-efficacy, resilience, hope, and optimism) has received special attention because it was showed to play a crucial role in influencing performance and in creating a virtuous circle between individual and organization. More simply, PsyCap generates positive emotions that could be used by individuals "for proactive extra-role behaviors such as sharing creative ideas or making suggestions for improvement" [11] (p. 133). Finally, these positive behaviors could be very much useful for organizational success because they could become a drive for performance [12,13].

In line with these assumptions, Gupta, Shaheen, and Reddy [14] showed that employees high in PsyCap tend not only to display extra-role behavior toward their colleagues (e.g., helping colleagues with their work) but also to engage in proactive extra-role behaviors toward their organization (e.g., being punctual, working overtime) which could directly contribute to maximizing organizational efficiency. Furthermore, the study by Gupta and colleagues also showed a significant mediating role of work engagement in this relationship. Accordingly, starting from the social exchange theory framework [15] of work engagement, that is, the extent to which employees show dedication, vigor, and enthusiasm for their work [16], has been largely proved to be a relevant antecedent of positive organizational behaviors, such as task performance and extra-role behaviors [17,18]. Consistently, Conservation of Resources theory also postulates that individuals who possess resources are capable of gaining more resources because of the "gain spiral" effect [19]. In fact, the loss of resources leads to low morale and lack of motivation, whereas the gain of resources leads to more absorption and immersion in tasks. Indeed, engaged employees tend to perform extra-role behaviors to reciprocate the benefits they receive from the organization in terms of supportive environment, consistency of values, and commitment to employee growth. Therefore, prior research confirmed that the more employees perceive a fit in values and practices with the working context, the more they would engage in their work, and consequently they would perform extra-role behaviors [20]. The aim of the study was to examine the positive relationship between PsyCap and extra-role behavior, investigating if and to what extent work engagement could be a mediator of this relationship. More simply, the study moved from the assumption that if the organization invests in practices addressed to develop employees' human and psychological capital, then the latter would probably engage in their job with stronger dedication and involvement, finally enacting positive organizational behaviors that are beneficial to the organization as well, such as, in this case, extra-role behaviors. 
In this respect, organizations could invest in employees' psychological capital through several Human Resource Management practices [21,22]. More simply, research suggests that by providing employees with decision-making discretion and by encouraging and supporting information sharing, organizations could concretely contribute to minimize incivility behavior, could give performance feedback, and foster workers' personal resources, finally impacting a positive adjustment between job demands and resources.

This evidence leads to further highlight the strategic role of human resource management practices and the need to focus on HR management systems that, through an evidence-based approach, could demonstrate the connection between employees' behavior and organizational competitive advantage [23]. These results were further confirmed by rich literature on the topic: HRM practices help the organization to develop a positive relationship with employees, increase motivation, and give meaning and sense to the organizational behavior of workers. Moreover, HR practices contribute to create, transform, and develop knowledge as a crucial and distinctive resource [24,25], useful to support the organizational survival, especially in times of turbulent and rapid changes such as the present post-pandemic ones [26,27].

In view of the above, the aim of the present study was to give a contribution to this rich strand of research examining the relationship between employees' psychological capital and their extra-role behaviors, and assuming a mediating role of work engagement in this link.

\section{Conceptual Framework and Research Hypotheses Development}

\subsection{The Impact of Psychological Capital on Work Engagement and Extra-Role Behavior}

As consistently showed by decades of empirical evidence, personal resources have been proven to be precious to manage challenging job demands and stressful experiences at work. Among the most authoritative scientific contributions in this direction, the J-D/R model and the CoR (Conservation of Resources) theory represent two crucial milestones.

According to the J-D/R model, any occupation is characterized by the presence of potentially challenging job demands (e.g., workload, emotional demands) that could require workers' sustained physical or psychological effort and strain, menacing their health and wellbeing. To manage this challenge, workers may rely upon job resources (e.g., career opportunities, supervisor coaching, role-clarity, and autonomy) and personal resources (e.g., self-efficacy, optimism, resilience), contrasting the effect of stress and burnout and increasing their motivation, work engagement and performance. However, the relationship between job demands and job resources may generate work engagement and motivation as well as stress and burnout, depending both on workers' perceptions and on the particular work environment. Job resources particularly influence motivation or work engagement when job demands are high. This evidence is particularly attuned with the Conservation of Resources (CoR) theory [28]. According to this theory, people are motivated to obtain, retain, and protect their resources, because they value them consistently. To this purpose, Hobfoll [28] argues that resources could acquire higher saliency in the context of resource loss. This implies that job resources gain their motivational potential particularly when employees are confronted with high job demands. For example, when employees have to cope with a stressful workload and pressures, the support of their colleagues and/or of their supervisor might become useful and instrumental. Furthermore, personal resources might moderate the relationship between job demands and exhaustion, might mediate the relationship between job resources and work engagement, and relate to how employees perceive their work environment and well-being [29]. Therefore, according to both perspectives, personal resources, psychological capital in this case, could be a potential motivational drive contributing to decrease emotional exhaustion, strain, and fatigue, and to increase levels of work engagement and positive work-related behaviors.

In view of the above, as highlighted earlier, in recent years, the construct of Psychological Capital (PsyCap) assumed increasing importance both from the employee and from the organizational point of view. The importance of PsyCap is given by the evidence that 
underlines the positive relationship between strategic resources (that is, those that are precious, rare, and difficult to imitate or replace) and organizational performance [30]. Accordingly, PsyCap could be considered as part of the so-called Human Capital, namely, a strategic resource that can contribute to sustainability and competitive advantage of organizations: a universally valuable and imperfectly imitable resource [31-33].

Luthans and his co-authors [10] described PsyCap as an individual's positive psychological state of development encompassing four positive psychological resources: selfefficacy, optimism, hope, and resilience. Based on Bandura's social cognitive theory [34], self-efficacy refers to an individual's confidence in his/her ability to mobilize motivation, cognitive resources, and courses of action to take on and put in the necessary effort to succeed at challenging tasks [35]. Optimism refers to an individual's expectancy about positive outcomes [36] and making a positive attribution about succeeding in the present and in the future. Hope refers to an individual's motivation to succeed at a specific task in a set context, persevering toward goals and, when necessary, redirecting paths to goals [37]. Finally, resilience consists of the ability of an individual to bounce back from adversity, uncertainty, risk, or failure, and adapt to changing and stressful life demands [38,39].

These four psychological resources, called by the acronym 'HERO' see e.g., [40], were proved to be highly important in producing exceptional capabilities and outcomes both at an individual and at an organizational level [41,42]. Many studies suggested that PsyCap has a significant impact on Positive Organizational Behavior (POB); it represents the outcome of the "application of positively oriented human resource strengths and psychological capacities that can be measured, developed and effectively managed for performance improvement in today's workplace" [3] (p. 59).

The basic underlying theoretical thread connecting PsyCap to POB is that it is the result of a positive evaluation of one's ability to succeed [43-45]. For this reason, those who show high levels of PsyCap tend to choose challenging objectives and to invest energy and resources in pursuing these objectives, despite any eventual obstacle and setback [46,47].

Since PsyCap is defined as a personal resource, it is positively linked with employee work performance including engagement to work, job satisfaction, work motivation, etc. It represents an important strategic lever for companies. Over the past decade, many studies have investigated the relationship between PsyCap and employee attitudes, behavior, and performance at the individual-level [44,48-50] and retention intentions; see [11], metaanalytical review. For example, Avey et al. [11], in their meta-analysis, discovered a positive correlation between PsyCap and some measures for job performance, organizational citizenship behaviors, satisfaction, and commitment.

At the individual level, specifically addressed by the present study, a construct that was found to be constantly related to PsyCap is Work Engagement, defined by Kahn [51] as "harnessing of organization members' selves to their work roles; in engagement, people employ and express themselves physically, cognitively, and emotionally during role performance" (p. 693). Accordingly, work engagement, which is composed of vigor (the willingness to invest energy and to engage in work), dedication (experiencing a sense of significance and pride), and absorption (a state of mind of such involvement and immersion in work), is afundamental concept to understand and to describe, both qualitatively and quantitatively, the nature of the relationship between the organization and its employees, being a significant correlate of motivation, morale, performance, and productivity.

In line with these assumptions, and adopting the wider framework of Positive Psychology, Bakker and Leiter [52] theoretically and empirically explained the relationship between the dimensions of PsyCap and work engagement. Sweetman and Luthans [53] highlighted how employees experiencing high levels of self-efficacy in accomplishing tasks and in managing processes would tend to be absorbed in their job and to feel more motivated to achieve goals. At same time, optimist employees would tend to consider and face job challenges expecting to succeed, and would be less exposed to the risk of failure, contributing to buffer the negative impact of stressful conditions. Hope represents an important psychological resource allowing persistence in the pursuit of goals and seek- 
ing alternative paths in case of difficulty. Finally, resilience allows employees to adapt positively to the adversities and changes required by the organization, strengthening the ability to manage complex situations. Although four PsyCap dimensions are conceptually well-distinguished [54], self-efficacy, hope, resilience, and optimism share salient features, i.e., effort and perseverance, internalized sense of agency, control, intentionality, positivity, and goal orientation $[55,56]$. Empirically speaking, the four dimensions are often used as first-order factors for measuring PsyCap as a second-order factor [57,58]. As a matter of fact, Luthans and colleagues [43] have well argued the theoretical and methodological reasons according to which the first-order factor of PsyCap may well represent the common variance among self-efficacy, hope, optimism, and resilience. Based on this evidence, our study assumed that:

\section{Hypothesis 1 (H1). PsyCap is positively related to work engagement.}

In addition to work engagement representing a fundamental dimension for employees' organizational performance, another construct of great interest placed in relation with PsyCap is OCBs. Nowadays, companies are looking for more and more potential employees who are concentrated, addicted, and are willing to work beyond what is foreseen by their roles $[52,53,59]$. Extra-role behaviors are a component of the wider construct of OCBs, defined by Organ [60] as "an individual behavior that is discretionary, not directly recognized by the formal reward system and that in the aggregate promotes the effective functioning of the organization" (p. 4). OCBs refer to all those voluntary behaviors that are not expected as formal job requirements and duties in a job description; they can be performed optionally and can be fully beneficial for the organization [61]. These behaviors might include helping, cooperating with and supporting colleagues, volunteering extra work, and sharing creative and innovative ideas. Turnispeed and Rassuli [62] defined OCBs as extra-role behaviors such as teamwork with colleagues, starting work earlier and finishing later, helping other employees, liking and caring for the organization, and spreading this positive behavior in the organization. The positive return for organizations is considerable: OCBs improve organizational attractiveness for potential new recruits with a consequent reduction in managerial expenses, improve co-worker and managerial productivity, provide better coordination of organizational activities across individuals, groups and functional departments, provide superior efficiency in resource use and allocation, enhance organizational capability to adapt effectively to environmental changes, and increase stability in the organization's performance [63]. Since these are voluntary employee behaviors that benefit the organization, the interest of companies and of the scientific literatures for the onset of such behaviors is taken for granted. For this reason, research focused on identifying those individual and organizational conditions that might incentivize employees to carry out extra-role behaviors to the benefit of the organization. Previous research highlighted how the presence of a high level of PsyCap among employees could help employees complete the tasks assigned to them in the allotted time, and helps make them more satisfied with their work environment $[45,64,65]$. Scholars argued that PsyCap might generate positive emotions, and individuals could use these positive emotions "for proactive extra-role behaviors such as sharing creative ideas or making suggestions for improvement" [11] (p. 133). Employees' PsyCap contributes to fueling progressive change through facilitating positive work outcomes like OCBs $[43,66]$. Examining the effectiveness of PsyCap in predicting attitudes and behaviors related to the job, Avey, Luthans, and Youssef [50] found that PsyCap was positively related with extra-role OCBs, whereas it is negatively related with undesired organizational attitudes such as cynicism, intentions to quit, and counterproductive workplace behaviors. The research by Beal et al. [67], which considered PsyCap, resistance to change, and OCBs, confirmed a positive relationship between PsyCap and organizational citizenship behaviors. According to the studies in question so far, PsyCap states seem to have a significant impact not only on in-role/work performance, but lead to positive attitudes towards the organization, intentions (eg, intention to remain), and "contextual" behaviors (discretionary behaviors) 
such as OCBs $[45,66,68,69]$. Indeed, employees with high PsyCap are expected to express not only positive behavior toward their colleagues but also to engage in proactive extra-role behaviors toward their organization [14].

Given these evidence-based premises, and considering PsyCap a personal resource that could significantly impact on employees' organizational behavior, a second hypothesis was formulated:

\section{Hypothesis 2 (H2). PsyCap is positively related to Extra-Role behavior.}

\subsection{PsyCap and Extra-Role Behaviors: The Mediating Role of Work Engagement}

Being a set of extra-role behaviors, OCBs do not simply depend on personal resources such as PsyCap, but rather could be linked to different kinds of employees' attitudes towards work, to work engagement, and to work commitment. Engaged employees have abundant personal resources and tend to invest them in their job, going the extra mile for organizational flourishing [70]. Employees who love their job, who feel deeply involved in it, and who are strongly committed to achieving the work goals from which they derive great personal satisfaction, are inclined to adopt behaviors that are not required by their job and by the organization, although the latter will take great advantage from this situation [71,72].

If it seems obvious enough that work engagement is linked to in-role performance, allowing employees to excel by reaching high success standards, it is interesting to note how work engagement might have an impact also on extra-role performance. Extra-role or contextual performance is defined as employee voluntary behaviors that directly promote the effective functioning of an organization without necessarily impacting employee productivity [73]. A study by Demerouti and colleagues [63] showed the significant relationship between work engagement, flourishing, and extra-role behavior, considering that employees' commitment to work and their overall state of well-being might generate positive behaviors towards the organization. Similarly, a meta-analysis conducted by Christian, Garza, and Slaughter [74] demonstrated that work engagement had incremental value in explaining variance of contextual performance indicators, much more than positive attitudes such as job satisfaction, job involvement, and organizational commitment. Often, extra-role behaviors or OCBs have been considered a type of commitment, but in truth, research showed that work engagement might positively influence in-role and extra-role behaviors, such as OCBs $[75,76]$. Employees who are psychologically engaged in their work and feel committed to their company will be much more likely to devote more time and effort to activities not required by their role, that is, performing a wide range of extra-role behaviors [77].

Moreover, Macey and Schneider [78] highlighted that a state of engagement is positively related to positive behaviors, such as OCBs, that represent those discretionary behaviors to the advantage of the organization. Engaged employees will be more involved in OCBs, as having effectively achieved their work objectives, they feel able to perform extra-role behaviors [74]. More specifically, it is believed that when employees are more absorbed and dedicated to their work, they will be more likely to engage in behaviors that are altruistic, conscientious, and virtuous.

Based on these previous arguments and on the empirical evidence reviewed in this section, the following hypothesis was proposed.

\section{Hypothesis 3 (H3). Work engagement is positively related to extra-role behavior.}

Considering these assumptions, the current study aimed to relate the variables considered to understand how psychological capital of employees might influence extra-role behavior via work engagement. Yet, following the assumptions proposed by the CoR theory described earlier, it could be argued that employees endowed with many resources would tend to be more engaged in their job because of the "gain spiral" effect [19]. Accordingly, work engagement could be considered as a form of absorption in one's own task, 
while PsyCap could provide the necessary strengths and abilities to stay engaged [53]. In a similar vein, according to the theory of social exchange [15], employees who are highly engaged in their job would be more motivated to reciprocate the benefits received from their organization with positive behavior often not formally required by their role. Therefore, employees with high levels of PsyCap and high levels of work engagement would feel more motivated to express gratitude to their organization by performing extra-role and voluntary behaviors which will favor organizational growth and flourishing. Consequently, the third hypothesis assumed that:

Hypothesis 4 (H4). Work Engagement mediates the relationship between PsyCap and ExtraRole Behavior.

\section{Materials and Methods}

The present study was the result of a collective research project carried out by a national research group, called Work in Progress (WiP), which was developed within the Italian Association of Psychology (section Work and Organizational Psychology), involving academics from several different Italian universities sharing a common research interest, synthetized by the name of the group. In 2020, WiP collected data on a national basis to investigate if and to what extent some organizational and personal resources could contribute to promote wellbeing at work and organizational performance. The research design, the development of the protocol (e.g., the choice of variables and measures), and data collection were the result of a proactive and conjoint effort brought about by most of the WiP members belonging to different Italian universities, coordinated by the authors of the present study. The research group agreed upon the fact that the data collected in each national context were then available for all members to allow further elaborations and future research developments.

According to the research protocol, researchers selected employees via a snowball procedure, beginning with the employees who were easier to be reached by the researchers. The inclusion criteria were: (1) employees aged $\geq 18$ years; (2) employees having a subordinate employment contract. The questionnaires were administered through an online platform, following ethical guidelines. Online information consent was requested by clicking on apposite button.

\subsection{Participants}

Participants were 1219 Italian employees, balanced for gender $(45.7 \%$ women and $54.3 \%$ men), aged 36.69 years on average (SD $=12.98)$. Most participants were employed in the private sector $(64.2 \%)$, while $33 \%$ were employed in the public sector and only $2.8 \%$ were employed in third sector organizations. As for their education, $93.4 \%$ of participants possessed at least a high school diploma, and $43.5 \%$ of them also took a university degree.

\subsection{Measures}

Psychological capital was assessed using the Italian version of the Psychological Capital Questionnaire [44-57]. This questionnaire encompasses 24 items (e.g., "I am enthusiastic about my job"), on a seven-point Likert scale ranging from 1 (strongly disagree) to 7 (strongly agree), assessing the four dimensions of psychological capital: hope, optimism, resilience, and self-efficacy. The scale also provides an overall measure of psychological capital [57]. High total scores indicate high levels of psychological capital.

Work Engagement was assessed adopting the short Italian version of the Utrecht Work Engagement Scale (UWES-9) [79,80]. This scale consists of nine items (e.g., "I am enthusiastic about my job") and investigates employees' perception about the absorption, vigor, and dedication they feel toward their job through an overall measure. The items were scored on a frequency scale ranging from 0 (never) to 6 (always). The validation study of the UWES-9 [80], conducted in ten investigated countries, showed psychometric properties comparable to those of the original version of the scale, with a very good level of reliability. 
In addition, the Italian validation [79] suggested that the UWES-9 was a reliable (Cronbach's alpha $=0.92)$ scale. Furthermore, UWES-9 was positively related to performance and to well-being scales, and negatively to displeasure dimensions. A recent meta-analysis [81]) pointed out that most of the studies available in literature used the UWES-9 than UWES-3 or UWES-17. Therefore, in line with several previous studies, we preferred using the short version of UWES-9 because it had a good scale for work engagement measuring. High total scores indicate high levels of employee's engagement.

Extra-role behavior was assessed by the Extra-Role Behaviors Scale [82], which is composed of four items, on a Likert scale ranging from 1 (strongly disagree) to 5 (strongly agree). This scale measures the discretional and positive behaviors towards colleagues and the organization (e.g., "I volunteer to do things for this organization"). High scores suggest high levels of extra-role behaviors.

\subsection{Data Analysis}

Preliminarily, Harman's single-factor test was used to examine the common method variance via Structural Equation Modeling (SEM) by M-Plus 8.53. Thus, a model with three latent factors (PsyCap, Work Engagement and Extra-role behaviors) was compared to an alternative model with an overall factor, i.e., a model in which all observed variables loaded into a single latent variable. In order to evaluate the goodness of models, the following fit indices were considered: Tucker-Lewis index (TLI), comparative fit index (CFI), the root mean square error of approximation (RMSEA), and the standardized root mean square residual (SRMR). According to previous studies, TLI and CFI values could be accepted if scoring around or greater than 0.90, and as for RMSEA and SRMR acceptable values need to score lower than 0.08 [83], therefore the three-factor model should be preferred because the single-factor model fitted significantly worse than the first.

SEM was also performed to test the hypotheses. Specifically, a mediation model was carried out to test the total and direct effect of psychological capital on extra-role behaviors, as well as the indirect effect via work engagement. All effects were also assessed via bootstrapping [84] with 5000 bootstrap samples and a 95\% confidence interval.

All SEM analyses were performed by a combination of total and partial disaggregation approaches [85]. As the psychological capital scale consisted of more than five items, a partially disaggregated approach was adopted, where latent factors were defined using parcels, i.e., the average of some items measuring the latent variable [86]. As previously described, psychological capital was composed of four correlated dimensions; therefore, four parcels for this latent variable were defined by the scores derived from the items related to hope, optimism, resilience, and self-efficacy. As suggested by Barbaranelli and colleagues [87], this approach could be used when there is a global high-order construct, as in this case, because the total score of PsyCap, including some correlated first-order factors, is directly defined by the items. Finally, since work engagement and extra-role behavior were measured by a limited number of items, latent variables were defined using all their corresponding items, without parcels.

\section{Results}

\subsection{Preliminary Analysis and Measurement Model}

Table 1 reports descriptive statistics, correlations and Cronbach's alpha for each variable.

PsyCap was positively associated with work engagement and extra-role behaviors, and work engagement was also positively associated with extra-role behaviors. Furthermore, the four PsyCap dimensions were positively associated to both work engagement and extra-role behaviors. Moreover, three latent variables, i.e., PsyCap, work engagement, and extra-role behaviors, showed a good internal consistency, reporting Cronbach's alpha coefficients between 0.91 and 0.95 . Finally, asymmetry and kurtosis indices did not violate normality assumptions, justifying the use of the method of Maximum Likelihood estimation for subsequently analyses. 
Table 1. Descriptive statistics and correlations.

\begin{tabular}{|c|c|c|c|c|c|c|c|c|c|c|c|}
\hline & Mean & SD & Asymmetry & Kurtosis & 1 & 2 & 3 & 4 & 5 & 6 & 7 \\
\hline 1. Self-efficacy & 23.65 & 5.60 & -1.06 & 0.52 & 0.91 & $0.76^{* *}$ & $0.73^{* *}$ & $0.54^{* *}$ & $0.89 * *$ & $0.41 * *$ & $0.42 * *$ \\
\hline 2. Hope & 22.53 & 5.54 & -0.82 & 0.16 & & 0.90 & $0.68 * *$ & $0.60 * *$ & $0.89 * *$ & $0.52 * *$ & $0.40 * *$ \\
\hline 3. Resilience & 23.11 & 4.54 & -0.72 & 0.19 & & & 0.78 & $0.60 * *$ & $0.87 * *$ & $0.35 * *$ & $0.39 * *$ \\
\hline 4. Optimism & 21.91 & 4.08 & -0.06 & -0.44 & & & & 0.59 & $0.77^{* *}$ & $0.46^{* *}$ & $0.34 * *$ \\
\hline 5. Psychological capital & 22.80 & 4.28 & -0.95 & 0.69 & & & & & 0.93 & $0.51^{* *}$ & $0.45^{* *}$ \\
\hline 6. Work engagement & 32.86 & 9.22 & -0.56 & -0.49 & & & & & & 0.95 & $0.54^{* *}$ \\
\hline 7. Extra-role behaviors & 15.15 & 4.14 & -0.66 & -0.37 & & & & & & & 0.91 \\
\hline
\end{tabular}

Notes: Values along main diagonal are Cronbach's. ${ }^{* *} p<0.01$.

To assess the common method variance, the hypothesized three-factor model was compared to the single-factor model, following Harman's test and delta $\chi^{2}$. The fit indices of two models are reported in Table 2.

Table 2. Results of measurement models' comparison.

\begin{tabular}{ccccccccc}
\hline Models & $\chi^{2}$ & df & CFI & TLI & RMSEA & SRMR & $\Delta \chi^{2}$ & $\Delta$ df \\
\hline $\begin{array}{c}\text { Hypothesized } \\
\text { three-factor model }\end{array}$ & 1851.41 & 116 & 0.90 & 0.88 & 0.10 & 0.04 & - & - \\
Single-factor model & 5980.49 & 119 & 0.66 & 0.61 & 0.20 & 0.12 & 4129.08 & 3 \\
\hline
\end{tabular}

The hypothesized three-factor model showed acceptable global fit indices: $\mathrm{CFI}=0.90$; $\mathrm{TLI}=0.88 ; \mathrm{RMSEA}=0.10, \mathrm{SRMR}=0.04$. Furthermore, each latent factor was significantly related to its own observed variables, reporting standardized factor loadings between 0.69 and 0.89 . Conversely, the single-factor model reached a very poor fit. As the difference between two models, with delta $\chi^{2}(\mathrm{df}=3)=4129.08, p<0.001$, was significant, we concluded that the hypothesized three-factor model better fitted than the alternative one-factor model.

\subsection{Hypotheses Test}

The hypothesized mediation model, including direct effect, showed an adequate global fit to the data: $\mathrm{CFI}=0.90$; TLI $=0.88$; $\mathrm{RMSEA}=0.11$, SRMR $=0.05$.

The SEM results showed that PsyCap had a significant and positive effect both on extra-role behaviors, $\beta=0.50$, and work engagement, $\beta=0.55$. These results suggested that employees with high levels of PsyCap tend to be more engaged at work and to enact positive behaviors towards colleagues and organization. Therefore, these findings supported $\mathrm{H} 1$ and $\mathrm{H} 2$.

Additionally, work engagement was significantly and positively related to extrarole behaviors, $\beta=0.42$, supporting H3. Results suggested that employees with high engagement tend to perform positive behaviors towards colleagues and organization.

Finally, PsyCap had a significant and positive direct effect on extra-role behaviors, $\beta=0.27$, as well as an indirect effect via work engagement, $\beta=0.23$. These results suggested that PsyCap contributed to increased extra-role behaviors levels in the presence of work engagement. In other words, work engagement partially mediated the positive relationship between PsyCap and extra-role behaviors supporting H4. All estimates were significant, also, considering $95 \%$ confidence interval via bootstrapping (Table 3 ).

Table 3. Results of standardized estimates at $95 \%$ confidence interval via bootstrapping.

\begin{tabular}{|c|c|c|c|c|c|c|c|}
\hline & $<0.5 \%$ & $<2.5 \%$ & $<5 \%$ & Estimate & $>0.5 \%$ & $>2.5 \%$ & $>5 \%$ \\
\hline Total effect & 0.412 & 0.435 & 0.445 & 0.500 & 0.551 & 0.560 & 0.580 \\
\hline Indirect effect & 0.169 & 0.183 & 0.190 & 0.227 & 0.264 & 0.271 & 0.283 \\
\hline Direct effect & 0.169 & 0.195 & 0.207 & 0.273 & 0.340 & 0.354 & 0.380 \\
\hline
\end{tabular}

The mediation model was reported in Figure 1. 


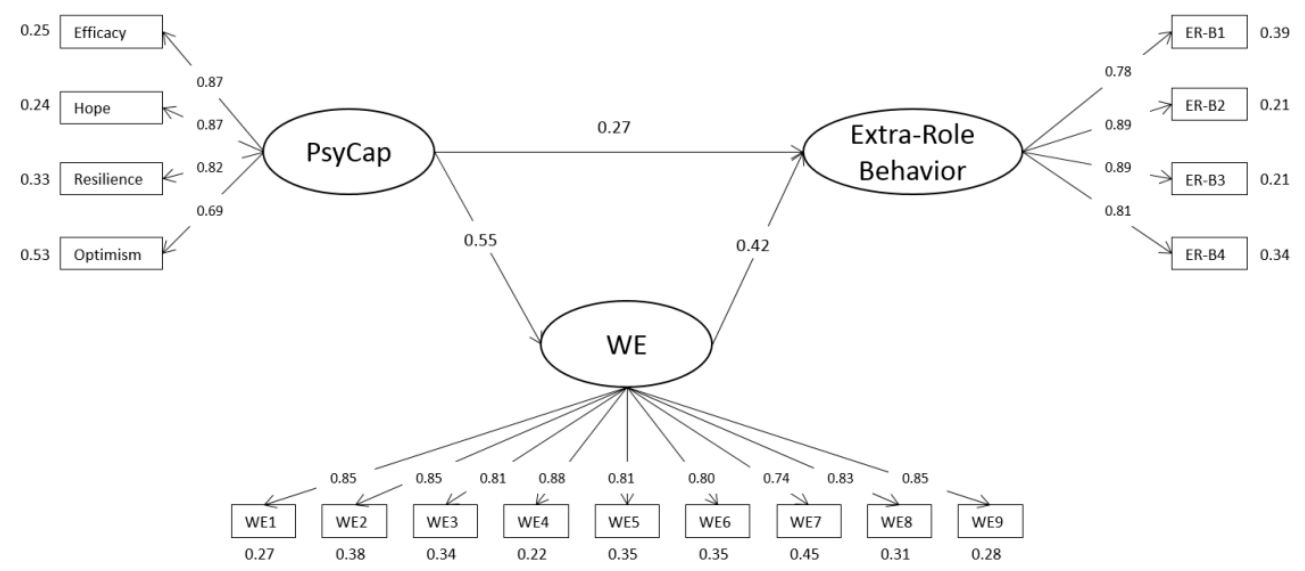

Figure 1. Mediation model with direct and indirect effect. Notes: Efficacy, resilience, hope and optimism = Parcel of PsyCap; WE1-WE9 = items of Work Engagement (WE); ER-B1-ER-B4 = items of Extra-Role Behavior.

\section{Discussion}

The aim of the study was to investigate the role played by work engagement in the relationship between psychological capital and extra-role behavior. Results revealed the importance of the human factor in organizations and the central role played by Person/Organization fit in encouraging positive organizational behavior. These findings produced valid insights both for future research and for practical development of professional practices within organizations.

Specifically, results confirmed our hypotheses, in line with what was found by the literature. The model showed a relation between psychological capital and work engagement (H1), between psychological capital and extra-role behaviors (H2), and between work engagement and extra-role behaviors (H3). Moreover, the relationship between psychological capital and extra-role behaviors was showed to be mediated by work engagement $(\mathrm{H} 4)$.

Yet, results were fully consistent with the objectives of the present study arising from the desire to understand the impact of personal resources on the activation of motivational processes towards one's work and the organization, supporting positive organizational behaviors even in difficult conditions.

According to the JD-R model, personal resources (in this case PsyCap) have an intrinsic potential to motivate and guide people at work, thus leading to high levels of work engagement [88]. In this regard, results regarding H1 confirmed what was found in the literature: employees with a high PsyCap tend to have a positive concept of themselves and their abilities and therefore commit themselves more to their goals [43]. This happens because the employees are intrinsically motivated to achieve the set goals, and consequently tend to feel more engaged. Therefore, this finding is consistent with previous studies confirming that psychological capital and resources in general play an active and dynamic role in increasing the level of work engagement $[89,90]$. Tenacity, perseverance, and a solid belief in future success push employees to be more engaged [91,92]. Therefore, results showed that employees with good control in carrying out their working tasks and managing the working context, employees who tend to face work and work challenges with optimism expecting to be successful, persisting in the pursuit of objectives and taking action proactively to overcome any obstacles and, finally, employees who show good resilience skills, who positively adapt to changes and difficulties, will be more dedicated to their work, will work with greater vigor and dedication, and will show higher levels of involvement. In this regard, there are three types of interventions that aim to enhance the psychological capital of employees: (1) Interventions that focus on providing an opportunity for employees to analyze themselves from different angles. This can help them find a 'best self' of themselves at work, which means focusing on strengths, contributions, and enduring talents that each person brings to a situation $[93,94]$. Usually, these types 
of interventions produce an increase in the feelings of being engaged, energized, and fulfilled in one's role [95]; (2) Solution-focused coaching interventions which emphasize strength-development and solution-generation methods instead of problem analysis [96], thanks to which employees, by focusing on goal setting, improve hope [45] and selfefficacy [97]; (3) Interventions aimed at transferring valued organizational characteristics to individuals, by identifying life-giving forces and core strengths within the organization to reach organizational goals. This approach may produce higher motivation and feelings of cooperation among organizational members.

In a similar vein, results relating to $\mathrm{H} 2$ (the impact of the PsyCap on extra-role behaviors) confirmed the positive and direct relationship between psychological capital and employees' attitudes and behaviors. There are plenty of previous studies that already demonstrated the impact of psychological capital on work performance [43,92-98]. However, this study contributed to enlarge this perspective, showing that employees who feel they could rely upon their personal resources (namely their PsyCap) not only tend to feel more motivated to engage in their work, but also tend to give a voluntary extra-role contribution to their colleagues and to their organization, positively impacting both individual and organizational performance. Many studies provided convincing evidence for the relationship between PsyCap and positive behaviors such as OCBs [11,99-103]. The present results were in line with the findings of a study by Prihatsanti [104] emphasizing how positive behavior could promote extra-role behavior and consequently organizational success. Positively oriented human strengths and human capacities encourage performance by employees that exceeds the minimum role requirements expected by the organizations [105]. These results are also further supported by another study by Rehman et al. [106], who also found that there is a significant positive relationship between PsyCap and OCB. Another study by Khosravizadeh et al. [107] also supported the results of this study. The authors found that employees high in PsyCap had a positive approach to their work environment, leading to extra-role work behavior. Furthermore, employees were confident and optimistic about the work outcomes; hence, they exhibited voluntary work behaviors [108]. Consistent with these studies, results also showed that the relevance of PsyCap goes beyond its direct impact on in-role performance; rather, it could positively influence "contextual" and discretionary behaviors such as OCBs that could be highly beneficial for organizations in the long term $[45,49,68,69]$. This suggests that organizations should invest in the psychological capital of their employees, as it might represent a significant antecedent of extra-role behaviors which, precisely because they are not required by the role, benefit the organization, and increase its competitive advantage.

Likewise, results showed that work engagement also had a significant influence on employees' extra-role behavior (H3). Yet, past research showed that work engagement positively engraves in-role and extra-role behaviors, such as OCBs $[75,76]$. Employees who are psychologically engaged in their work and with their company are led to engage more in tasks that their job role does not require, dedicating more time and effort to extra-work and relationship issues, that is, extra-role behavior and OCBs [77]. They also tended to act more responsibly and constructively in their work and were more likely to engage in extra-role performance $[109,110]$. Engaged employees may exhibit OCB because they accomplish their tasks efficiently and, therefore, feel able to take on extra responsibilities [111]. As expected, highly engaged employees showed themselves willing to take personal initiatives, to generate new ideas, and to commit in making an extra-role contribution to organizational goals as they experience high levels of work positivity. The results demonstrated that when employees are highly motivated, they perform their tasks effectively and efficiently, thereby broadening their resource capabilities. This, too, fosters OCB. Engaged employees with a passion for their work have a strong connection to their organization, and will put in extra effort to improve not only their own performance, but also that of the overall organization [112]. Therefore, the confirmation of this hypothesis showed that the organization should invest in increasing the levels of work engagement of its employees, putting the right people in the right place, allowing employees to express 
their potential, and granting autonomy and creativity, as long as work engagement is a positive resource, and when job resources are high, the level of motivation among employees also tends to be high, regardless of the demands placed on them [113,114].

Finally, as regards $\mathrm{H} 4$, results confirmed the partial mediation of work engagement in the relationship between PsyCap and extra-role behavior. This means that work engagement was significantly influential in its effect on extra-role behavior, and this suggests that work engagement may become even more crucial when employees are faced with increasingly greater job demands, but have adequate personal resources, such as PsyCap, that are available to deal with these job demands. However, resulting in work engagement as a partial mediator, this study has mapped out a research framework which suggests there are reciprocal and simultaneous relationships between a predictor (PsyCap), work engagement, and consequent variables, as already highlighted by the study by Paek et al. [115]. This is critical from an organizational psychology perspective, because the partial mediating role of work engagement shows the importance of the direct relationships between the variables considered (PsyCap, work engagement, and extra-role behavior), and suggests important intervention indications for organizations. This result represented the core of the research and was very interesting, as it revealed that employees display voluntary work behaviors toward the organization only when they feel they could rely upon high levels of psychological capital, because they feel they are resilient to work challenges, and they are committed and engaged in their work. Employees who can count on a rich stock of personal resources useful for managing job demands are also those who tend to feel more committed to their work and to offer their support and help to colleagues and to the organization, displaying altruistic and sportsmanship attitudes and behaviors. From an organizational point of view, the results highlighted the need to better investigate the strategies and practices that could contribute to developing and maintaining a positive person/organization relationship, for instance fostering organizational support, adopting a charismatic leadership style, or appropriate people-based HR practices aimed to empower employees' growth, and to inspire in-role and extra-role positive behaviors.

\section{Limitations, Practical Implications, and Conclusions}

Although the results of this research provided a significant contribution to confirming what previous research demonstrated in relation to the variables investigated above, some limitations should be highlighted. The first limitation was related to the cross-sectional nature of the study; this prevented us from verifying any causal relationships between the variables and from monitoring the trend of results over time. Considering the great changes that the world and the labor market are experiencing due to the pandemic and how this situation might have affected the variables considered, it would have been interesting to analyze the impact that these changes (e.g., in terms of job insecurity, working modalities, relationships among colleagues, etc.) could have had on people and over time through longitudinal studies.

Another limitation could be found in the impossibility of generalizing the results due to the heterogeneity of the sample and the relatively small dependence. The convenience sample set up through the online procedure did not allow for guiding the collection by allowing us to make comparisons between some categories or some characteristics; in fact, the sample appears to be very heterogeneous due to the presence of different professional categories (e.g., blue collar workers, white collar workers, managers), for different occupational sectors, and for the type of contract with the company.

Another limit could be represented by the evidence that results could not be generalized due to the limitedness and heterogeneity of the sample. Indeed, the convenience sample recruited through the online procedure and social media channels did not allow for the comparison of different professional categories, types of companies, types of contracts, or working conditions. Furthermore, results could be influenced by the period in which the data was collected, that is, the advent of the pandemic. it would be interesting to replicate 
the study at different times by controlling variables that may be linked to the changes that the pandemic has induced in the work.

Moreover, another possible limitation of the study was related to the risk of common method bias [116], due to the characteristics of the measuring instruments, which could have caused spurious effects due to the measuring instruments rather than to the constructs, and of self-report measures. To overcome the errors caused by the choice of measurement instruments, future research could use different endpoints and scale formats and compare employee perceptions with objective measures of the same constructs.

Despite the limitations set out, the research showed interesting results, especially in terms of practical implications and suggestions for organizations. Specifically, the value of the study was the further acknowledgement of the importance of psychological capital in organizational contexts, having assessed its impact on organizational behavior. The link between psychological capital and extra-role behaviors, via engagement, underlined the fact that to possess a set of personal resources is useful not only to manage job demands, but also to foster organizational citizenship behaviors. Therefore, understanding how to recognize, enhance, and invest in the psychological capital of employees becomes a competitive factor for organizations. The scientific debate between a "trait" or "state" view of PsyCap is still open, however a widely shared position suggests that PsyCap is a "developmental state" open to change and potentially trainable through targeted HRM interventions $[37,44,49,117]$. Certainly, PsyCap is significantly related to desirable attitudes, behaviors, and performance outcomes, as showed by the meta-analysis by Avey and colleagues [11]. Therefore, the main lesson learned through this study was that any investment in PsyCap training programs could represent a winning and "sustainable" HR strategy, aimed at improving the potential of individuals and teams and at increasing the competitive advantage of the organizations, which is a high-order priority, especially in the current unstable and complex times.

Author Contributions: Conceptualization, M.L.G., A.M. and A.C.; Data curation, A.C.; Formal analysis, A.C.; Investigation, M.L.G. and A.M.; Methodology, M.L.G., A.M. and A.C.; Project administration, M.L.G. and A.M.; Software, A.C.; Supervision, M.L.G. and A.M.; Writing—original draft, M.L.G., A.M. and A.C.; Writing—review \& editing, M.L.G., A.M. and A.C. All authors have read and agreed to the published version of the manuscript.

Funding: This research received no external funding.

Institutional Review Board Statement: The study was conducted in accordance with the Declaration of Helsinki, and approved by the Ethics Committee of Lumsa University of Rome (protocol code 4/2021 at 6 May 2021).

Informed Consent Statement: Informed consent was obtained from all subjects involved in the study.

Data Availability Statement: The data presented in this study are available on request from the corresponding author. The data are not publicly available due to privacy reasons.

Acknowledgments: The authors would like to thank the Italian research group "WiP" for the data collection and the scientific support given to this paper.

Conflicts of Interest: The authors declare no conflict of interest.

\section{References}

1. Taamneh, A.; Alsaad, A.K.; Elrehail, H. HRM practices and the multifaceted nature of organization performance: The mediation effect of organizational citizenship behavior. EuroMed. J. Bus. 2018, 13, 315-334. [CrossRef]

2. Zhao, C.; Cooke, F.L.; Wang, Z. Human resource management in China: What are the key issues confronting organizations and how can research help? Asia Pac. J. Hum. Resour. 2021, 59, 357-363. [CrossRef]

3. Luthans, F. The need for and meaning of positive organizational behavior. J. Organ. Behav. Intern. J. Ind. Occup. Organ. Psychol. Behav. 2002, 23, 695-706. [CrossRef]

4. Luthans, F.; Youssef, C.M. Emerging positive organizational behavior. J. Manag. 2007, 33, 321-349. [CrossRef]

5. Spreitzer, G.; Porath, C. Creating sustainable performance. Harv. Bus. Rev. 2012, 90, 92-99.

6. Wright, B.W. Comic Book Nation: The Transformation of Youth Culture in America; JHU Press: Baltimore, MD, USA, 2003. 
7. Zwetsloot, G.; Pot, F. The business value of health management. J. Bus. Ethics 2004, 55, 115-124. [CrossRef]

8. Cameron, K.S.; Dutton, J.E.; Quinn, R.E. An introduction to positive organizational scholarship. Pos. Organ. Sch. 2003, 3, 2-21.

9. Cameron, K.S.; Caza, A. Introduction: Contributions to the discipline of positive organizational scholarship. Amer. Behav. Sci. 2004, 47, 731-739. [CrossRef]

10. Luthans, F.; Youssef, C.M.; Avolio, B.J. Psychological Capital and Beyond; Oxford University Press: Oxford, MS, USA, 2015. [CrossRef]

11. Avey, J.B.; Reichard, R.J.; Luthans, F.; Mhatre, K.H. Meta-analysis of the impact of positive psychological capital on employee attitudes, behaviors, and performance. Hum. Resour. Dev. Quart. 2011, 22, 127-152. [CrossRef]

12. Sanders-Reio, J.; Alexander, P.A.; Reio Jr, T.G.; Newman, I. Do students' beliefs about writing relate to their writing self-efficacy, apprehension, and performance? Learn. Instr. 2014, 33, 1-11. [CrossRef]

13. Nolzen, N. The concept of psychological capital: A comprehensive review. Manag. Rev. Quart. 2018, 68, 237-277. [CrossRef]

14. Gupta, M.; Shaheen, M.; Reddy, P.K. Impact of psychological capital on organizational citizenship behavior: Mediation by work engagement. J. Manag. Dev. 2017, 36, 973-983. [CrossRef]

15. Blau, P. Exchange and Power in Social Life; Wiley: New York, NY, USA, 1964; p. 352.

16. Schaufeli, W.B.; Salanova, M.; González-Romá, V.; Bakker, A.B. The measurement of engagement and burnout: A two sample confirmatory factor analytic approach. J. Happ. Stud. 2002, 3, 71-92. [CrossRef]

17. Alfes, K.; Shantz, A.D.; Truss, C.; Soane, E.C. The link between perceived human resource management practices, engagement and employee behaviour: A moderated mediation model. Int. J. Hum. Resour. Manag. 2013, 24, 330-351. [CrossRef]

18. Tims, M.; Bakker, A.B.; Derks, D. Daily job crafting and the self-efficacy-performance relationship. J. Manag. Psychol. 2014, 29, 490-507. [CrossRef]

19. Hobfoll, S.E.; Wells, J.D. Conservation of resources, stress, and aging. In Handbook of Aging and Mental Health; Springer: Boston, MA, USA, 1998; pp. 121-134.

20. Reijseger, G.; Schaufeli, W.B.; Peeters, M.C.; Taris, T.W. Ready, set, go! A model of the relation between work engagement and performance. In Occupational Health Psychology: From Burnout to Well-Being; Goncalves, S.P., Ed.; Scientific \& Academic Publishing Co.: London, UK, 2012; pp. 289-306.

21. Tims, M.; Bakker, A.B.; Derks, D.; Van Rhenen, W. Job crafting at the team and individual level: Implications for work engagement and performance. Group Organ. Manag. 2013, 38, 427-454. [CrossRef]

22. Van Wingerden, J.; Bakker, A.B.; Derks, D. Fostering employee well-being via a job crafting intervention. J. Vocat. Behav. 2017, 100, 164-174. [CrossRef]

23. Noe, R.A.; Hollenbeck, J.R.; Gerhart, B.; Wright, P.M. Menadžment Ljudskih Potencijala; Mate: Zagreb, Croatia, 2006 ; p. 688.

24. Lindgren, R.; Stenmark, D.; Ljungberg, J. Rethinking competence systems for knowledge-based organizations. Eur. J. Inform. Syst. 2003, 12, 18-29. [CrossRef]

25. Manuti, A.; Impedovo, M.A.; De Palma, P.D. Managing social and human capital in organizations: Communities of practices as strategic tools for individual and organizational development. J. Workpl. Learn. 2017, 29, 217-234. [CrossRef]

26. Kniffin, K.M.; Narayanan, J.; Anseel, F.; Antonakis, J.; Ashford, S.P.; Bakker, A.B.; Vugt, M.V. COVID-19 and the workplace: Implications, issues, and insights for future research and action. Am. Psychol. 2021, 76, 63. [CrossRef]

27. Rudolph, C.W.; Allan, B.; Clark, M.; Hertel, G.; Hirschi, A.; Kunze, F.; Zacher, H. Pandemics: Implications for research and practice in industrial and organizational psychology. Indust. Organ. Psychol. 2021, 14, 1-35. [CrossRef]

28. Hobfoll, S.E. Conservation of resources: A new attempt at conceptualizing stress. Am. Psychol. 1989, 44, 513-524. [CrossRef] [PubMed]

29. Xanthopoulou, D.; Bakker, A.B.; Demerouti, E.; Schaufeli, W.B. The role of personal resources in the job demands-resources model. Int. J. Str. Manag. 2007, 14, 121. [CrossRef]

30. Crook, T.R.; Ketchen, D.J., Jr.; Combs, J.G.; Todd, S.Y. Strategic resources and performance: A meta-analysis. Strat. Manag. J. 2008, 29, 1141-1154. [CrossRef]

31. Crook, T.R.; Todd, S.Y.; Combs, J.G.; Woehr, D.J.; Ketchen, D.J., Jr. Does human capital matter? A meta-analysis of the relationship between human capital and firm performance. J. Appl. Psychol. 2011, 96, 443. [CrossRef]

32. Grant, R.M. Prospering in dynamically-competitive environments: Organizational capability as knowledge integration. Organ. Sci. 1996, 7, 375-387. [CrossRef]

33. Kogut, B.; Zander, U. Knowledge of the firm, combinative capabilities, and the replication of technology. Organ. Sci. 1992, 3, 383-397. [CrossRef]

34. Bandura, A. Self-efficacy: Toward a unifying theory of behavioral change. Psychol. Rev. 1977, 84, 191-215. [CrossRef]

35. Stajkovic, A.D.; Luthans, F. Self-efficacy and work-related performance: A meta-analysis. Psychol. Bull. 1998, 124, 240. [CrossRef]

36. Scheier, M.F.; Carver, C.S.; Bridges, M.W. Optimism, pessimism, and psychological well-being. In Optimism E Pessimism: Implications for Theory, Research, and Practice; Chang, E.C., Ed.; American Psychological Association: Washington, DC, USA, 2001; pp. 189-216. [CrossRef]

37. Luthans, F.; Norman, S.M.; Avolio, B.J.; Avey, J.B. The mediating role of psychological capital in the supportive organizational climate-Employee performance relationship. J. Organ. Behav. 2008, 29, 219-238. [CrossRef]

38. Masten, A.S.; Reed, M.G.J. Resilience in development. Handb. Pos. Psychol. 2002, 74, 88. [CrossRef]

39. Tugade, M.M.; Fredrickson, B.L. Resilient individuals use positive emotions to bounce back from negative emotional experiences. J. Pers. Soc. Psychol. 2004, 86, 320. [CrossRef] [PubMed] 
40. Luthans, F. Psychological capital: Implications for HRD, retrospective analysis, and future directions. Hum. Resour. Dev. Quart. 2012, 23, 21119. [CrossRef]

41. Gil-Beltrán, E.; Llorens Gumbau, S.; Salanova, M. Employees' physical exercise, resources, engagement, and performance: A cross-sectional study from HERO Model. J. Work Organ. Psychol. 2020, 36, 39-47. [CrossRef]

42. Sánchez-Cardona, I.; Ortega-Maldonado, A.; Salanova, M.; Martínez, I.M. Learning goal orientation and psychological capital among students: A pathway to academic satisfaction and performance. Psychol. Sch. 2021, 58, 1432-1445. [CrossRef]

43. Luthans, F.; Youssef, C.M.; Avolio, B.J. Psychological capital: Investing and developing positive organizational behavior. Pos. Organ. Behav. 2007, 1, 9-24. [CrossRef]

44. Luthans, F.; Avolio, B.J.; Avey, J.B.; Norman, S.M. Positive Psychological Capital: Measurement and relationship with performance and satisfaction. Pers. Psychol. 2007, 60, 541-572. [CrossRef]

45. Luthans, F.; Youssef, C.M. Human, social, and now positive psychological capital management: Investing in people for competitive advantage. Organ. Dyn. 2004, 33, 143-160. [CrossRef]

46. Luthans, F.; Youssef, C.M.; Sweetman, D.S.; Harms, P.D. Meeting the Leadership Challenge of Employee Well-Being through Relationship PsyCap and Health PsyCap. J. Lead. Organ. Stud. 2013, 20, 118-133. [CrossRef]

47. Youssef-Morgan, C.M.; Luthans, F. Positive leadership: Meaning and application across cultures. Organ. Dyn. 2013, 42, 198-208. [CrossRef]

48. Larson, M.; Luthans, F. Potential added value of psychological capital in predicting work attitudes. J. Lead. Organ. Stud. 2006, 13, 75-92. [CrossRef]

49. Luthans, F.; Avey, J.B.; Avolio, B.J.; Norman, S.M.; Combs, G.M. Psychological capital development: Toward a micro-intervention J. Organ. Behav. 2006, 27, 387-393. [CrossRef]

50. Avey, J.B.; Luthans, F.; Youssef, C.M. The additive value of positive psychological capital in predicting work attitudes and behaviors. J. Manag. 2010, 36, 430-452. [CrossRef]

51. Kahn, W.A. Psychological conditions of personal engagement and disengagement at work. Acad. Manag. J. 1990, 33, 692-724. [CrossRef]

52. Bakker, A.B.; Leiter, M.P. Work Engagement: A Handbook of Essential Theory and Research, 1st ed.; Psychology Press: Hove, UK, 2010. [CrossRef]

53. Sweetman, D.; Luthans, F. The power of positive psychology: Psychological capital and work engagement. In Work Engagement: A Handbook of Essential Theory and Research; Bakker, A.B., Leiter, M.P., Eds.; Psychology Press: Hove, UK, 2010; pp. 54-68.

54. Luthans, F.; Avey, J.B.; Patera, J.L. Experimental analysis of a web-based training intervention to develop positive psychological capital. Acad. Manag. Learn. Educ. 2008, 7, 209-221. [CrossRef]

55. Dudasova, L.; Prochazka, J.; Vaculik, M.; Lorenz, T. Measuring psychological capital: Revision of the Compound Psychological Capital Scale (CPC-12). PLoS ONE 2021, 16, e0247114. [CrossRef] [PubMed]

56. Luthans, F.; Youssef-Morgan, C.M. Psychological capital: An evidence-based positive approach. Annu. Rev. Organ. Psychol. Organ. Behav. 2017, 4, 339-366. [CrossRef]

57. Alessandri, G.; Borgogni, L.; Consiglio, C.; Mitidieri, G. Psychometric properties of the Italian version of the psychological capital questionnaire. Int. J. Sel. Assess. 2015, 23, 149-159. [CrossRef]

58. Sharp, R. Career crescendo: An experimental analysis of a 6-week work-site intervention to determine the developmental capacity of psychological capital. J. Manag. Dev. 2019, 38, 719-732. [CrossRef]

59. Adams, G.A.; Prescher, J.; Beehr, T.A.; Lepisto, L. Applying work-role attachment theory to retirement decision-making. Int. J Aging Hum. Dev. 2002, 54, 125-137. [CrossRef]

60. Organ, D.W. Organizational Citizenship Behavior: The Good Soldier Syndrome; Lexington Books/D.C. Heath and Com.: Lexington, MA, USA, 1988.

61. Lambert, E.G.; Pasupuleti, S.; Cluse-Tolar, T.; Jennings, M.; Baker, D. The impact of work-family conflict on social work and human service worker job satisfaction and organizational commitment: An exploratory study. Admin. Soc. Work. 2006, 30, 55-74. [CrossRef]

62. Turnispeed, D.L.; Rassuli, A. Performance Perceptions of Organizational Citizenship Behaviours at Work: A Bi-Level Study among Managers and Employees. Brit. J. Manag. 2005, 16, 231-244. [CrossRef]

63. Cohen, A.; Vigoda, E. Do good citizens make good organizational citizens? An empirical examination of the relationship between general citizenship and organizational citizenship behavior in Israel. Admin. Soc. 2000, 32, 596-624. [CrossRef]

64. Luthans, F.; Jensen, S.M. Hope: A new positive strength for human resource development. Hum. Resour. Dev. Rev. 2002, 1, 304-322. [CrossRef]

65. Wright, T.A.; Cropanzano, R.; Bonett, D.G. The moderating role of employee positive well being on the relation between job satisfaction and job performance. J. Occup. Health Psychol. 2007, 12, 93-104. [CrossRef] [PubMed]

66. Avey, J.B.; Wernsing, T.S.; Luthans, F. Can positive employees help positive organizational change? Impact of psychological capital and emotions on relevant attitudes and behaviors. J. Appl. Behav. Sci. 2008, 44, 48-70. [CrossRef]

67. Beal, L., III; Stavros, J.M.; Cole, M.L. Effect of psychological capital and resistance to change on organisational citizenship behaviour. SA J. Ind. Psychol. 2013, 39, 1-11. [CrossRef]

68. Gooty, J.; Gavin, M.; Johnson, P.D.; Frazier, M.L.; Snow, D.B. In the eyes of the beholder: Transformational leadership, positive psychological capital, and performance. J. Lead. Organ. Stud. 2009, 15, 353-367. [CrossRef] 
69. Motowidlo, S.J.; Van Scotter, J.R. Evidence that task performance should be distinguished from contextual performance. J. Appl. Psychol. 1994, 79, 475-480. [CrossRef]

70. Demerouti, E.; Bakker, A.B.; Gevers, J.M. Job crafting and extra-role behavior: The role of work engagement and flourishing. J. Vocat. Behav. 2015, 91, 87-96. [CrossRef]

71. Dalal, R.S. A meta-analysis of the relationship between organizational citizenship behavior and counterproductive work behavior. J. Appl. Psychol. 2005, 90, 1241. [CrossRef] [PubMed]

72. KeIlies, R.; Nahrgang, J.D.; Morgeson, F.P. Leader-member exchange and citizenship behaviors: A meta-analysis. J. Appl. Psychol. 2007, 92, 269. [CrossRef]

73. MacKenzie, S.B.; Podsakoff, P.M.; Fetter, R. Organizational citizenship behavior and objective productivity as determinants of managerial evaluations of salespersons' performance. Organ. Behav. Hum. Dec. Proc. 1991, 50, 123-150. [CrossRef]

74. Christian, M.S.; Garza, A.S.; Slaughter, J.E. Work engagement: A quantitative review and tests of its relations with task and contextual performance. Pers. Psychol. 2011, 64, 89-136. [CrossRef]

75. Babcock-Roberson, M.E.; Strickland, O.J. The relationship between charismatic leadership, work engagement, and organizational citizenship behaviors. J. Psychol. 2010, 144, 313-326. [CrossRef]

76. Hassan, Z.; Saleem, Z.; Rajput, A.A. The mediating role of employee engagement between the relationship of distributive justice and organizational citizenship behavior: Empirical evidence from aviation sector of Pakistan. Int. J. Manag. Sci. 2014, 2, 494-500.

77. Farid, T.; Iqbal, S.; Ma, J.; Castro-González, S.; Khattak, A.; Khan, M.K. Employees' perceptions of CSR, work engagement, and organizational citizenship behavior: The mediating effects of organizational justice. Int. J. Environ. Resour. Public Health 2019, 16, 1731. [CrossRef]

78. Macey, W.H.; Schneider, B. The meaning of employee engagement. Ind. Organ. Psychol. 2008, 1, 3-30. [CrossRef]

79. Balducci, C.; Fraccaroli, F.; Schaufeli, W.B. Psychometric properties of the Italian version of the Utrecht Work Engagement Scale (UWES-9). Eur. J. Psychol. Assess. 2010, 26, 143-149. [CrossRef]

80. Schaufeli, W.B.; Bakker, A.B.; Salanova, M. The Measurement of Work Engagement with a Short Questionnaire: A Cross-National Study. Educ. Psychol. Meas. 2006, 66, 701-716. [CrossRef]

81. Mazzetti, G.; Robledo, E.; Vignoli, M.; Topa, G.; Guglielmi, D.; Schaufeli, W.D. Work Engagement: A meta-Analysis Using the Job Demands-Resources Model. Psychol. Rep. 2021, 1-38. [CrossRef] [PubMed]

82. George, E.; Levenson, A.; Finegold, D.; Chattopadhyay, P. Extra-role behaviors among temporary workers: How firms create relational wealth in the United States of America. Int. J. Hum. Resour. Manag. 2010, 21, 530-550. [CrossRef]

83. Hu, L.; Bentler, P.M. Cutoff criteria for fit indexes in covariance structure analysis: Conventional criteria versus new alternatives. Struct. Equ. Modeling J. 1999, 6, 1-55. [CrossRef]

84. Preacher, K.J.; Hayes, A.F. Asymptotic and resampling methods for estimating and comparing indirect effects. Behav. Resour. Meth. 2008, 40, 879-891. [CrossRef] [PubMed]

85. Bagozzi, R.P.; Heatherton, T.F. A general approach to representing multifaceted personality constructs: Application to state self-esteem. Struct. Equat. Model. A Multidiscip. J. 1994, 1, 35-67. [CrossRef]

86. Coffman, D.L.; MacCallum, R.C. Using parcels to convert path analysis models into latent variable models. Multiv. Behav. Resour. 2005, 40, 235-259. [CrossRef]

87. Barbaranelli, C.; Farnese, M.L.; Tramontano, C.; Fida, R.; Ghezzi, V.; Paciello, M.; Long, P. Machiavellian ways to academic cheating: A mediational and interactional model. Front. Psychol. 2018, 9, 695. [CrossRef]

88. Lorente, L.; Salanova, M.; Martínez, I.M.; Vera, M. How personal resources predict work engagement and self-rated performance among construction workers: A social cognitive perspective. Int. J. Psychol. 2014, 49, 200-207. [CrossRef]

89. Ouweneel, E.; Le Blanc, P.M.; Schaufeli, W.B. Don't leave your heart at home: Gain cycles of positive emotions, resources, and engagement at work. Career Dev. Intern. 2012, 17, 537-556. [CrossRef]

90. Xanthopoulou, D.; Bakker, A.B.; Demerouti, E.; Schaufeli, W.B. Reciprocal relationships between job resources, personal resources, and work engagement. J. Vocat. Behav. 2009, 74, 235-244. [CrossRef]

91. Xanthopoulou, D.; Bakker, A.B.; Demerouti, E.; Schaufeli, W.B. Work engagement and financial returns: A diary study on the role of job and personal resources. J. Occup. Organ. Psychol. 2009, 82, 183-200. [CrossRef]

92. Youssef, C.M.; Luthans, F. An integrated model of psychological capital in the workplace. In Oxford Handbook of Positive Psychology and Work; Linley, P.A., Harrington, S., Garcea, N., Eds.; Oxford University Press: Oxford, UK, 2020; pp. $277-288$.

93. Costantini, A.; De Paola, F.; Ceschi, A.; Sartori, R.; Meneghini, A.M.; Di Fabio, A. Work engagement and psychological capital in the Italian public administration: A new resource-based intervention programme. SA J. Ind. Psychol. 2017, 43, 1-11. [CrossRef]

94. Roberts, L.M.; Dutton, J.E.; Spreitzer, G.M.; Heaphy, E.D.; Quinn, R.E. Composing the reflected best-self portrait: Building pathways for becoming extraordinary in work organizations. Acad. Manag. Rev. 2005, 30, 712-736. [CrossRef]

95. Peterson, C.; Seligman, M. Character Strengths and Virtues: A Handbook and Classification; Oxford University Press: New York, NY, USA, 2004.

96. Grant, R.M. Strategic planning in a turbulent environment: Evidence from the oil majors. Str. Manag. J. 2003, $24,491-517$. [CrossRef]

97. Grant, A.M.; Curtayne, L.; Burton, G. Executive coaching enhances goal attainment, resilience and workplace well-being: A randomised controlled study. J. Posit. Psychol. 2009, 4, 396-407. [CrossRef] 
98. Peterson, S.J.; Luthans, F.; Avolio, B.J.; Walumbwa, F.O.; Zhang, Z. Psychological capital and employee performance: A latent growth modeling approach. Pers. Psychol. 2011, 64, 427-450. [CrossRef]

99. Görgens-Ekermans, G.; Herbert, M. Psychological capital: Internal and external validity of the Psychological Capital Questionnaire (PCQ-24) on a South African sample. SA J. Ind. Psychol. 2013, 39, 1-12. [CrossRef]

100. Pradhan, R.K.; Jena, L.K.; Bhattacharya, P. Impact of psychological capital on organizational citizenship behavior: Moderating role of emotional intelligence. Cogent Bus. Manag. 2016, 3, 1194174. [CrossRef]

101. Bogler, R.; Somech, A. Psychological Capital, Team Resources and Organizational Citizenship Behavior. J. Psychol. 2019, 153, 784-802. [CrossRef]

102. Chamisa, S.F.; Mjoli, T.Q.; Mhlanga, T.S. Psychological capital and organisational citizenship behaviour in selected public hospitals in the Eastern Cape Province of South Africa. SA J. Hum. Resour. Manag. 2020, 18, 12. [CrossRef]

103. Da, S.; Zhu, Z.; Cen, H.; Gong, X.; Siu, O.L.; Zhang, X. Psychological Capital, Positive Affect, and Organizational Outcomes. J. Pac. Rim Psychol. 2021, 15, 18344909211010514. [CrossRef]

104. Prihatsanti, U. The role of psychological capital among Indonesian's worker. J. Ed. Health Com. Psychol. 2017, 6, 68-83. [CrossRef]

105. Kim, M.; Kim, A.C.H.; Newman, J.I.; Ferris, G.R.; Perrewé, P.L. The antecedents and consequences of positive organizational behavior: The role of psychological capital for promoting employee well-being in sport organizations. Sport Manag. Rev. 2019, 22, 108-125. [CrossRef]

106. Rehman, S.U.; Qingren, C.; Latif, Y.; Iqbal, P. Impact of psychological capital on occupational burnout and performance of faculty members. Intern. J. Educ. Manag. 2017, 31, 455-469. [CrossRef]

107. Khosravizadeh, O.; Vatankhah, S.; Alirezaei, S.; Doosty, F.; Mousavi Esfahani, H.; Rahimi, M. Organizational Citizenship Behavior and its Relationship with Psychological Capital: A Survey of Hospital Staffs. Evid. Based Health Policy Manag. Econ. 2017, 1, 25-32.

108. Akin, K. The effect of teachers' shared leadership perception on academic optimism and organizational citizenship behaviour: A Turkish case. Int. J. Lead. Educ. 2017, 20, 246-258. [CrossRef]

109. Schaufeli, W.B.; Taris, T.W.; Bakker, A.B. Dr. Jekyll or Mr. Hyde: On the differences between work engagement and workaholism. In Research Companion to Working Time and Work Addiction; Burke, R.J., Ed.; Edward Elgar Publishing Limited: Northampton, MA, USA, 2006; pp. 193-217.

110. Ariani, D.W. The relationship between employee engagement, organizational citizenship behavior, and counterproductive work behavior. Int. J. Bus. Admin. 2013, 4, 46. [CrossRef]

111. Sulea, C.; Virga, D.; Maricutoiu, L.P.; Schaufeli, W.; Zaborila, D.C.; Sava, F.A. Work engagement as mediator between job characteristics and positive and negative extra-role behaviors. Career Dev. Int. 2012, 17, 188-207. [CrossRef]

112. Sridhar, A.; Thiruvenkadam, T. Impact of employee engagement on organization citizenship behaviour. BVIMSRs J. Manag. Resour. 2014, 6, 147-155.

113. Bakker, A.B.; Demerouti, E. The Job Demands-Resources model: State of the art. J. Manag. Psychol. 2007, 22, 309-328. [CrossRef]

114. Du Plooy, J.; Roodt, G. Work engagement, burnout and related constructs as predictors of turnover intentions. SA J. Ind. Psychol. 2010, 36, 1-13. [CrossRef]

115. Paek, S.; Schuckert, M.; Kim, T.T.; Lee, G. Why is hospitality employees' psychological capital important? The effects of psychological capital on work engagement and employee morale. Int. J. Hosp. Manag. 2015, 50, 9-26. [CrossRef]

116. Podsakoff, P.M.; MacKenzie, S.B.; Lee, J.Y.; Podsakoff, N.P. Common method biases in behavioral research: A critical review of the literature and recommended remedies. J. Appl. Psychol. 2003, 88, 879-903. [CrossRef] [PubMed]

117. Luthans, F.; Avey, J.B.; Avolio, B.J.; Peterson, S.J. The development and resulting performance impact of positive psychological capital. Hum. Resour. Dev. Quart. 2010, 21, 41-67. [CrossRef] 